\title{
Pergeseran Pendekatan Ras Menjadi Kewarganegaraan Pada Hukum Perdata Tentang Orang (Studi Ketentuan Subjek Hak Milik atas Tanah dengan Politik Hukum Kewarganegaraan)
}

\author{
Siti Zulaekah \\ Fakultas Hukum Universitas Pekalongan \\ she_tea9875@yahoo.co.id
}

\begin{abstract}
Legal policy the rule of person that has shft from race approach to citizenship after Indonesian Independence is the subject of property rigths of land statued on the act no. 5 year 1960, the basic of the agrarian law. Embedded on this rule is the interface between citizenship system and the mix marrital that involved different citizenship, wife and husband, occured many problems. This conceptual/academic writing aims : first, to dig out the value arround shifting rule of person from race approach to citizenship approach. Second, the base of shifting rule of person from race approach to citizenship approach. The last, to eksplain the sincronize between the rule of person of property rights of land with the citizenship sistem. The results of this conceptual writing showed that race approach of the rule of person based on feodalism, individualism, and discrimination values, on the other hand the rule of person with citizenship approach based on nationalism values. Legal policy of the shifting approach from race to citizenship use the room of Pasal II Aturan Peralihan of the Indonesian Constitution (UUD 1945). There was sincronization between the subject of land property right with the citizenship system in Indonesia.
\end{abstract}

Keywords : race approach, nationality, private law

\begin{abstract}
Abstrak
Politik hukum pengaturan tentang orang yang telah bergeser dari pendekatan ras (golongan penduduk) menjadi kewarganegaraan pascakemerdekaan Indonesia adalah adalah ketentuan tentang subjek Hak Milik atas Tanah sebagaimana diatur dalam Undang-Undang Nomor 5 tahun 1960 tentang Ketentuan Dasar Pokok-Pokok Agraria (UUPA). Melekat dalam ketentuan tersebut adalah persinggungan sistem kewarganegaraan dengan perkawinan campuran yang dalam iimpementasinya banyak menimbulkan permasalahan. Telaaah konseptual/ilmiah ini bertujuan, pertama mengungkap nilai-nilai yang melatarbelakangi perubahan pengaturan tentang orang dari penggunaan pendekatan ras menjadi kewarganegaraan. Kedua, dasar perubahan pendekatan ras menjadi kewarganegaraan tersebut? Ketiga, menjelaskan ketentuan keselarasan subjek Hak Milik atas tanah dalam UUPA dengan politik hukum kewarganegaraan. Hasil telah akademik/konseptual menunjukkan, pengaturan hukum tentang orang dengan menggunakan pendekatan ras ditaltarbelakangi oleh nilai-nilai feodalisme, individualisme serta bersifat diskriminatif antargolongan penduduk yang sengaja ditanamkan oleh kolonial. Sebaliknya, pendekatan kewarganegaraan didasari nilai-nilai nasionalisme atau rasa kebangsaan. Ketentuan subjek Hak Milik atas tanah dalam UUPA telah sejalan dengan politik hukum kewarganegaraan.
\end{abstract}

Kata Kunci : pendekatan ras, kewarganegaraan, hukum perdata 


\section{Pendahuluan}

Proklamasi kemerdekaan Republik Indonesia pada tanggal 17 Agustus 1945 merupakan titik awal terbentuknya negara Indonesia. Manusia Indonesia dalam konteks pembentukan negara ini bukan dalam arti makhluk individu, tetapi sebagai makhluk sosial yang oleh Kranenburg dan Sabaroedin disebut sebagai makhluk berkerukunan atau makhluk golongan (Kranenburg dan Sabaroedin, 1983 : 29). Sebagaimana asa-usul keberadaan bangsa Indonesia, penduduk yang mendiami wilayah Indonesia sebagai negara kepulauan adalah beragamnya golongan-golongan penduduk. Diantara ragam golongan penduduk ada golongan penduduk lain seperti golongan Eropa, golongan China, golongan Arab, serta golongan penduduk timur asing lainnya yang datang untuk kepentingan perniagaan ataupun kepentingan lain.

Golongan Eropa yang mendominasi dan supreme atas golongan yang lain, Belanda yang menjajah Indonesia selama kurang lebih 350 tahun mewariskan Ilmu Hukum yang sangat berarti yakni kodifikasi Hukum Pidana melalui Wet Boek van Starft Recht (WvK), kodifikasi Hukum Perdata melalui Burgeliljke Wet Boek (BW), dan kodifikasi Hukum Dagang melalui Wet Boek van Koophandel (WvK).
Struktur BW mencakup : Buku I tentang Orang, Buku II tentang Kebendaan, Buku III tentang Perikatan, dan Buku IV tentang Pembuktian dan Daluwarsa. Substansi ketentuan Buku I tersebut diantaranya ketentuan tentang Perkawinan, Pewarisan, dan Subjek Hukum, baik Natural Persoon (subjek hukum orang) maupun Rechtspersoon (subjek hukum badan hukum). Kedudukan Buku I tersebut memiliki peranan yang sangat penting dan memiliki nilai sejarah yang bermakna. Sebagaimana diketahui, Buku I tersebut pada zaman Pemerintah Hindia-Belanda menggunakan pendekatan ras atau pembedaan berlakunya hukum berdasarkan golongan penduduk sebagaimana diatur Pasal 163 Indonesische Staatsregelling (IS). Berdasarkan ketentuan tersebut, penduduk Hindia-Belanda dibagi menjadi golongan penduduk Eropa, Timur Asing, dan Bumiputera dengan pemberlakuan hukumnya masingmasing. Menurut Daniel S. Lev, pemberlakuan Hukum Perdata berdasarkan patokan ras pada saat pengakuan kedaulatan Republik Indonesia hingga tahun 1949 masih berlaku dan pada tahun 1963 berdasarkan putusan Mahkamah Agung, KUHPerdata dinyatakan tidak berlaku lagi, Akan tetapi, keputusan ini 
menimbulkan berbagai pertanyaan terutama dari para penegak hukum (Lev, $1990: 78)$.

Meskipun sebuah kenyataan bahwa dalam negara terdiri atas beragam golongan penduduk, tetapi pemberlakukan hukum yang berbedabeda atasnya terkandung nilai diskriminasi terhadap golongan golongan penduduk tersebut bahkan terdapat kecenderungan sikap merendahkan kedudukan golongan penduduk pribumi/bumiputera. Pengaturan tentang orang dalam Hukum Perdata sangat rasial dan dianggap menyakiti perasaan golongan pribumi. Oleh karena itu, pengaturan hukum orang dengan pendekatan ras bertentangan dengan UUD 1945 dimana konstitusi tersebut mengakui persamaan kedudukan semua penduduk tanpa dibeda-bedakan asal-usul suku, ras, warna kulit, maupun agama.

Secara faktual pada masa kolonial tidak bisa dipungkiri atas merebaknya fenomena penundukkan hukum oleh golongan penduduk non Eropa karena adanya persamaan kepentingan hukum, terutama dalam bidang perniagaan menunjukkan bahwa secara fungsional pemberlakukan hukum berdasarkan golongan penduduk sudah tidak bisa lagi pertahankan. Berdasarkan inventarisasi Prof. Subekti, beberapa peraturan perundang-undangan yang diterbitkan jauh sebelum kemerdekaanpun diberlakukan untuk semua warga negara (Subekti, 2001 : 12). Peraturan perundang-undangan dimaksud diantaranya Undang-Undang Hak Pengarang (Auteurswet) 1912, Peraturan Umum tentang Koperasi (Staatsblad 1933 No. 108), Ordonansi Woeker (Staatsblad 1938 No. 523), dan Ordonansi tentang Pengangkutan di Udara (Staatsblad 1938 No. 98). Selama masa revolusi aturan perundangan baru tidak membeda-bedakan golongan rakyat/penduduk sehingga secara resmi satu-satunya perbedaan yang diakui adalah perbedaan antara warga negara dan bukan warga negara, artinya perbedaan berdasarkan status kwarganegaraan (Subekti, 2001 : 81).

Menyikapi kenyataan tersebut langkah penting pemerintah untuk menghentikan patokan ras tersebut adalah penerbitan Undang - undang Nomor 62 Tahun 1958 tentang Kewarganegaraan. Lahirnya undangundang ini merupakan bukti perubahan ideologi kolonial (pemberlakuan hukum berdasarkan golongan penduduk) menjadi ideologi nasional (pemberlakukan hukum berdasarkan status kewarganegaraan) sebagaimana termaktub dalam Pembukaan UUD 1945 :”...penjajahan diatas dunia harus 
dihapuskan". Dua tahun kemudian menyusul diterbitkan Undang - Undang Nomor 5 Tahun 1960 tentang PokokPokok Agraria (UUPA) yang menggunakan azas nasionalitas (kewarganegaraan) khususnya berkaitan dengan ketentuan subyek hak milik atas tanah.

Berdasarkan dari uraian tersebut, pertanyaan akademik makalah ini dirumuskan sebagai berikut : (1) Nilainilai apa sajakah yang mendasari pergeseran politik hukum dengan pendekatan ras menjadi kewarganegaraan dalam pengaturan hukum tentang orang di Indonesia ?, (2) Apakah dasar perubahan pemberlakuan ketentuan hukum tentang orang dari pendekatan ras menjadi kewarganegaraan ?, dan (3) Apakah ketentuan subyek hak milik atas tanah dalam UUPA telah selaras dengan politik hukum kewarganegaraan?

\section{Pembahasan}

\section{Pengertian Politik Hukum Menurut Beberapa Ahli}

Beberapa ahli mengartikan politik/pembaharuan/pembangunan hukum sebagai berikut :

1) Padmo Wahjono

Politik hukum didefinisikan sebagai kebijakan dasar yang menentukan arah, bentuk maupun isi dari hukum yang akan dibentuk. Kemudian, Padmo mendefinisikan arti tersebut secara lebih konkrit sebagai kebijakan penyelenggara negara tentang apa yang dijadikan kriteria untuk menghukumkan sesuatu (Wahjono, $1986: 160$ ).

2) Teuku Mohammad Radhie Politik hukum diartikan sebagai suatu pernyataan kehendak penguasa negara mengenai hukum yang berlaku di wilayahnya, dan mengenai arah perkembangan hukum yang akan dibangun (Prisma, 1973 : 4).

3) Soedarto

Politik hukum adalah kebijakan negara melalui badan-badan negara yang berwenang untuk menetapkan peraturanperaturan yang dikehendaki yang diperkirakan akan digunakan untuk mengekspresikan apa yang terkandung dalam masyarakat dan untuk mencapai apa yang dicita-citakan. Soedarto juga mengartikan politik hukum sebagai usaha untuk mewujudkan peraturanperaturan yang baik sesuai dengan keadaan dan situasi pada suatu waktu (Soedarto, 1986 : 151).

4) Satjipto Rahardjo

Politik berkaitan dengan pemilihan tujuan diantara berbagai tujuan yang mungkin sedangkan hukum harus senantiasa melakukan penyesuaian terhadap tujuan-tujuan yang ingin dicapai oleh masyarakatnya, dengan 
demikian hukum memiliki dinamika. Politik hukum merupakan salah satu faktor yang menyebabkan terjadinya dinamika yang demikian itu karena ia diarahkan ius constituendum, hukum yang seharusnya berlaku. Menurut Satjipto, studi politik hukum menimbulkan beberapa pertanyaan terkait tujuan sistem hukum yang ada, cara mencapai tujuan, waktu perubahan hukum berikut cara melakukan perubahan, kemungkinan perumusan pola yang mapan, perubahan dilakukan secara total atau bagian demi bagian (Rahardjo, 2006 : 358 - 359).

\section{5) C.F.G. Soenaryati Hartono}

Politik Hukum dimaknai sebuah alat (tool) atau sarana atau langkah yang dapat digunakan oleh pemerintah untuk menciptakan sistem hukum nasional yang dikehendaki dan dengan sistem hukum nasional itu akan diwujudkan cita-cita bangsa Indonesia (Hartono, $1991: 1)$.

6) Abdul Hakim Garuda Nusantara

Abdul Hakim Garuda Nusantara mendefinisikan politik hukum nasional sebagai kebijakan hukum yang hendak diterapkan atau dilaksanakan secara nasional oleh suatu pemerintahan negara tertentu. Bentuk implementasi politik hukum nasional mencakup : (1) pelaksanaan ketentuan hukum yang telah ada secara konsisten, pembangunan hukum yang intinya adalah pembaharuan terhadap hukum yang telah ada dan dianggap usang, dan penciptaan hukum baru yang diperlukan untuk memenuhi tuntutan perkembangan yang terjadi dalam masyarakat, (3) penegasan fungsi lembaga penegak atau pelaksana hukum dan pembinaan anggotanya, dan (4) meningkatkan kesadaran masyarakat menurut persepsi kelompok elit pengambil kebijakan (Nusantara, 1985 : 15).

7) Mochtar Kusumatmadja

Pandangan Mochtar Kusumaatmadja tentang pembangunan hukum berpangkal pada cara berfikir masyarakat Indonesia tentang hukum. Di satu sisi, orang hilang kepercayaan terhadap hukum, tetapi di lain pihak masyarakat pada umumnya memiliki kepercayaan yang naif terhadap kekuatan yang seakan-akan magis re ligius dari hukum. Berdasarkan argumentasi tersebut, maka pembangunan nasional adalah masalah pembaharuan cara berfikir, sikap hidup, sifat, dan nilai-nilai. Tanpa sikap dan cara berfikir yang berubah pengenalan lembaga-lembaga moderen dalam kehidupan tidak akan berhasil (Kusumaatmadja, $2006: 1$ ).

8) Siti Soetami

Pembinaan hukum artinya tidak saja membuat yang baru, tetapi juga 
menyesuaikan hukum yang ada di masyarakat.Hukum yang akan disusun adalah hukum yang moderen, bertujuan meningkatkan kemampuan sesuai kebutuhan yang memiliki ciri-ciri : konsentris artinya adanya satu tangan yang mengatur/membuat yaitu pengundang-undang, konvergen artinya hukum Indonesia bersifat terbuka terhadap perubahan dan perkembangan, dan tertulis untuk lebih menjamin kepastian hukum (Soetami, 2007 : 7).

9) Mahfud MD

Mahfud MD merumuskan politik hukum sebagai legal policy atau (kebijakan) resmi tentang hukum yang akan diberlakukan, baik dengan pembuatan hukum baru maupun dengan penggantian hukum lama, dalam rangka mencapai tujuan negara sebagaimana tercantum didalam Pembuakaan UUD 1945 (Mahfud, 2014 : 1).

Berdasarkan pendapat 10 (sepuluh) ahli hukum tersebut setidak-tidaknya terdapat tiga ciri yang sama dalam politik hukum yakni dibuat oleh penguasa (pihak berwenang), pembuatan hukum dilakukan dengan cara memilih nilai-nilai yang berkembang di masyarakat yang disepakati bersama dan kemudian dituangkan dalam norma untuk mengkaidahi perilaku bersama, dan bersifat constituendum yang memuat hukum ideal atau cita hukum yang akan diberlakukan. Terlepas dari ketiga persamaan tersebut, terdapat beberapa aspek politik hukum yang bersifat khusus dari pengertian yang disampaikan para ahli tersebut diantaranya apa yang disampaikan oleh Mochtar Kusumaatmaja yang tidak dikemukakan oleh ahli hukum lain. Mochtar lebih menekankan bahwa pembangunan hukum atau politik hukum sama dengan pembaharuan cara berfikir, sikap, dan nilai-nilai yang berkembang di masyarakat. Penulis menafsirkan bahwa pendapat Mochtar Kusumaatmaja didasarkan atas alasan penggerak terjadinya pembangunan hukum. Selain itu, Siti Soetami juga memiliki pandangan yang berbeda dimana salah satu hal dalam politik hukum adalah adanya keharusan hukum tertulis untuk menjamin kepastian hukum. Perbedaan pandangannya dipahami dalam konteks pembuatan hukum yang merupakan kesepakatan bersama dimana kewenangannya diberikan kepada pembuat undang undang.

Nilai-nilai yang Mendasari Perubahan Politik Hukum dengan Pendekatan Ras menjadi Pendekatan Kewarganegaraan dalam Pengaturan Hukum tentang Orang di Indonesia Masuknya Belanda ke Indonesia yang pada awalnya memiliki misi 
perdagangan dan kemudian berubah menjadi penjajahan, sesungguhnya membawa tradisi hukum dari negara asalnya. Tradisi tersebut diusung untuk membangun ideologi hukum negara di tengah nilai hukum sebelumnya yang telah berkembang dalam masyarakat, dalam hal ini hukum adat. Apabila di negara asalnya (Belanda) materialisasi hukum justru digunakan sebagai strategi untuk menghapuskan nilai-nilai feodalisme, di Indonesia justru sebaliknya, mengukuhkan nilai-nilai feodalisme.

Apabila dipandang dari perspektif Ilmu Hukum Normatif, setiap hukum memuat 2 (dua) unsur yang terdiri atas aspek norma secara lahiriah yang nampak dan terwujud dalam rumusan perundang-undangan dan aspek nilai dan hal ini juga berlaku untuk hukum kolonial Belanda yang dibawa ke Indonesia yakni aspek kejiwaan atau norma di balik peraturan perundangundangan, dalam hal ini Pasal 163 IS tersebut. Pemberlakuan hukum sipil di Indonesia, khususnya KUHPerdata dan KUHD, sebagaimana dijelaskan diatas bisa dilacak dari asal-muasal kedua kitab undang-undang tersebut sehingga nilainilai apa tersembunyi di balik norma tersebut bisa terjelaskan. Sistem Hukum yang sangat sarat dengan nilai-nilai individualisme, liberalisme, dan feodalisme yang berakibat pada sikap diskriminatif dalam pengaturan hukum tentang orang. Nilai-nilai feodalisme dalam norma hukum tersebut diantaranya terlihat untuk memberlakukan hukum tentang orang yang berbeda-beda terhadap golongan penduduk yang berbeda-beda pula.Sampai pada tahun1949, Hukum Perdata yang berpatokan ras tetap ada dan Kitab Undang-Undang Hukum Perdata (KUHPer/BW) merupakan lambang utama perbedaan orang per orang. Dengan demikian, nilai-nilai dalam hukum tersebut bersifat diskriminatif dan bertentangan dengan Undang-Undang Dasar 1945.

Pergeseran pendekatan ras menjadi kewarganegaraan dalam politik hukum tentang orang berarti mengapuskan sendi-sendi feodalisme yang merupakan bagunan nilai bagi penggolongan penduduk pada masa kolonial. Menyitir pendapat Ratno Lukito, hapusnya feodalisme harus diikuti dengan langkah besar yakni memuliakan negara sebagai sumber hukum (Lukito, 2013 : 97 - 98). Segala sesuatu yang mempunyai aspek hukum, ditentukan dan diatur oleh negara sebagai sumber hukum.

Seiring dengan ditinggalkannya nilai-nilai kolonial, orientasi diarahkan pada idiologi nasional yakni pembentukan national self identification 
- Salah satu konsekuensinya adalah penanaman nilai-nilai nasionalisme melalui pendekatan pengaturan hukum tentang orang dalam hal ini perasaan senasib dan seperjuangan dalam ikatan nation Indonesia. Biarpun demikian, kenyataan keragaman penduduk tidak bisa dihindari dan mereka dibalut atau diikat dengan pendekatan kewarganegaraan, sehingga siapapun yang berdiam di wilayah Negara Kesatuan hanya bisa dibedakan menjadi 2 (dua) yakni penduduk berkewarganegaraan Indonesia atau penduduk berkewarganegaraan asing.

Dasar perubahan pemberlakuan ketentuan hukum tentang orang dari pendekatan ras menjadi kewarganegaraan

Sebagai negara bekas penjajahan, Indonesia belum memiliki produk hukum yang dibuat sendiri. Hukum yang ada seperti BW, WvS, WvK, berikut hukum acaranya merupakan peninggalan Pemerintah Kolonial Belanda. Meskipun beberapa kitab undang-undang tersebut merupakan peninggalan kolonial, bukan berarti bahwa tata hukum Indonesia melanjutkan tata hukum kolonial. Semenjak pembacaan Proklamasi Kemerdekaan yang merupakan norma pertama atas tata hukum Indonesia adalah atas kekuatan proklamasi (Joeniarto, 1984 : 17). Kedudukan tata hukum Indonesia tersebut kemudian ditegaskan melalui pengaturan Pasal II Aturan Peralihan Undang-Undang Dasar Tahun 1945 yang pada intinya menyatakan bahwa segala Badan Negara dan Peraturan yang ada masih langsung berlaku, selama belum diadakan yang baru menurut Undang-Undang Dasar ini. Kedudukan aturan peralihan berfungsi untuk mengantisipasi terjadnya kekosongan hukum (rechts vakuum) dengan ketentuan peraturan perundangundangan lama masih tetap berlaku sepanjang belum ada ketentuan baru. Kedudukan pasal II aturan peralihan menurut penulis memposisikan Pemerintah Indonesia untuk mengambil tanpa syarat segara peraturan perundang-undangan peninggalan kolonial tersebut.Kemudian melalui Peraturan Pemerintah (dalam literatur lain aturan tersebut bernomenklatur “Maklumat Presiden") Nomor 2 Tahun 1945 tentang Peraturan Peralihan mensyaratkan bahwa pemberlakuan hukum peninggalan kolonial dibolehkan dengan 2 (dua) syarat yakni belum adanya peraturan perundang-undangan yang baru serta tidak bertentangan dengan Undang-Undang Dasar 1945. Kedua syarat tersebut bersifat kumulatif yang merupakan alasan pembenar atas pemberlakuan hukum kolonial yakni belum adanya hukum yang baru serta 
hukum yang lama tidak bertentangan dengan UUD 1945.

Keberadaan "Peraturan Pemerintah" atau "Maklumat Presiden" tersebut menunjukkan bahwa Pemerintah Indonesia memiliki kesempatan untuk melakukan pilihan-pilihan hukum apa yang sebaiknya diberlakukan. Dengan kata lain, kedudukan Peraturan Pemerintah/Maklmumat Presiden Nomor 2 Tahun 1945 terhadap Pasal II aturan peralihan UUD 1945 bersifat memagari/memberikan patokan dalam keadaan yang bagaimana warisan hukum kolonial diperbolehkan untuk diberlakukan di Indonesia yang semestinya menggunakan tata hukum sendiri yang baru. Dikaitkan dengan konsep politik hukum sebagaimana telah diuraikan para ahli diatas, maklumat presiden tersebut hakikatnya merupakan ruang untuk memilih hukum-hukum yang seperti apa yang akan diberlakukan di Indonesia. Dua unsur lain dari pengertian politik hukum sebagaimana dikemukakan para ahli bahwa hukum yang akan diberlakukan harus dibuat oleh pihak yang berwenang serta merupakan hukum yang dicitakan telah terpenuhi. Dapat disimpulkan bahwa Peraturan Pemerintah/Maklumat Presiden Nomor 2 Tahun 1945 tersebut merupakan pijakan bagi politik hukum tentang penggantian pendekatan ras menjadi kewarganegaraan dalam pengaturan hukum tentang orang.

\section{Sinkronisasi Ketentuan Subjek Hukum Hak Milik atas Tanah dengan Politik Hukum Kewarganegaraan}

Sebelum menganalisis permasalahan ketiga, perlu dijelaskan tentang konsep warga negara dalam konteks kenegaraan, pengertiannya menurut kamus, stelsel kewarganegaraan yang berlaku di Indonesia serta sistem kewarganegaraan yang diatur dalam peraturan perundangundangan. Warga negara merupakan salah satu syarat adanya negara yang merupakan pemberian status rakyat yang hidup di negara yang bersangkutan. Siti Sutami menegaskan bahwa masyarakat suatu negara adalah mereka yang bersama-sama menjadi anggota suatu organisasi sosial yang disebut negara. Tiap-tiap negara menurut Hukum Internasional berhak untuk menetapkan sendiri siapa yang menjadi warga negaranya (Sutami, 2007, 49). Kamus Besar Bahasa Indonesia (KBBI) mengartikan warga negara sebagai penduduk sebuah negara atau bangsa berdasarkan keturunan, tempat kelahiran dan sebagainya yang mempunyai kewajiban dan hak penuh sebagai seorang warga dari negara itu. Kewarganegaraan diartikan sebagai hal yang berkaitan dengan warga negara, 
keanggotaan sebagai warga negara (Sutami, 2007 : 49).

Secara teoritik, dikenal 2 (dua) azas/stelsel kwarganegaraan yakni azas ius sanguinis dan azas ius soli. Azas yang pertama merupakan azas dimana seseorang menjadi warga negara berdasarkan keturunan.Jadi seorang itu menjadi warga negara Indonesia karena ia dilahirkan dari orang tua yang berkwarganegaraan Indoensia. Sementara azas yang kedua adalah suatu azas dimana seorang menjadi warga negara berdasarkan tempat kelahiran. Jadi seseorang berkwarganegaraan Indonesia apabila yang bersangkutan dilahirkan di Indonesia. Selain kedua azas tersebut, tedapat azas lain berupa azas campuran yang merupakan penggabungan dari kedua azas yang telah dijelaskan diatas. Dari pengertian itu dapat disimpulkan bahwa setiap orang dapat menjadi warga negara atau bukan warga negara, dapat menjadi penghuni atau penduduk (Busroh, 1990 :

79). Sementara sistem kewarganegaraan yang dikenal di dunia ini terdapat 2(dua) macam yakni sistem kewarganegaraan tunggal dan kewarganegaraan ganda.

Secara historis, politik hukum kewarganegaraan bisa dirunut melalui riwayat lahirnya peraturan perundangundangan di bidang tersebut. Awalnya substansi pengaturannya perihal warga negara dan penduduk negara sebagaimana diatur melalui Undangundang Nomor 3 Tahun 1946, kemudian diubah dengan Undang-undang Nomor 6 Tahun 1947 hingga dilakukan perpanjangan terakhir melalui Undangundang Nomor 11 Tahun 1948. Baru pada tahun 1958 diterbitkan Undangundang Nomor 62 Tahun 1958 tentang Kewarganegaraan Republik Indonesia yang 18 tahun kemudian Pasal 18 dari undang-undang tersebut dirubah karena banyaknya kejadian di masyarakat bahwa orang yang tinggal di luar negeri kehilangan kewarganegaraan sehingga yang bersangkutan berstatus sebagai apatride (tanpa kewarganegaraan). Perubahan pasal tersebut merupakan bukti perlindungan penuh negara terhadap warga negaranya. Undangundang dirubah lagi dengan Undangundang Nomor 12 Tahun 2006 dengan nomenklatur yang sama dengan alasan mendasar perubahan 3 (tiga) unsur pokok produk hukum yakni unsur filosofis, unsur sosiologis dan unsur yuridis. Secara filosofis, undang-undang tersebut masih mengandung ketentuanketentuan yang belum sejalan falsafah Pancasila antara lain karerna bersifat diskriminatif, kurang menjamin pemenuhan hak asasi dan persamaan antarwarganegara, serta kurang memberikan perlindungan terhadap 
perempuan dan anak-anak. Secara yuridis, landasann konstitusional undang-undang tersebut adalah UndangUndang Dasar Sementara (UUDS) Tahun 1950 yang sudah tidak berlaku sejak Dekrit Presiden 5 Juli 1959 yang menyatakan kembali kepada UndangUndang Dasar 1945. Dalam perkembangannya, UUD 1945 telah mengalami perubahan yang lebih menjamin perlindungan terhadap hak asasi manusia dan hak warga. Terakhir, secara sosiologis, undang-undang tersebut sudah tidak sesuai lagi dengan perkembangan dan tuntutan masyarakat Indonesia sebagai bagian dari masyarakat Internasional dalam pergaulan global yang menghendaki persamaan perlakuan dan kedudukan warga negara dihadapan hukum serta negara serta adanya kesetaraan dan keadilan jender.

Sejak pertama terbit (tahun 1946 hingga tahun 2006) di Indonesia menganut sistem kewarganegaraan tunggal dengan perkecualian dimungkinkan diterapkannya sistem dwikewarganegaraan secara terbatas pada anak yang dilahirkan di Indonesia tetapi orang tuanya berasal dari negara yang menganut stelsel ius soli. Permasalahan ketiga ini menganalisis sinkronisasi antara ketentuan subjek Hak Milik atas Tanah sebagaimana diatur dalam Pasal 21 UUPA dengan politik hukum kewarganegaraan sebagaimana muatan norma Undang-Undang Nomor 12 Tahun 2006. Salah satu azas/prinsip yang dianut dalam UUPA adalah prinsip nasionalitas yang menegaskan bahwa Hak Milik atas tanah hanya bisa dimiliki oleh WNI.

Sebelum dianalisis, perlu dipaparkan terlebih dahulu isi lengkap Pasal 21 UUPA ayat (1), ayat (3), dan ayat (4) sebagai berikut :

(1) Hanya Warga Negara Indonesia dapat mempunyai tanah Hak Milik.

(2) Oleh pemerintah diatur badan hukum-badan hukum tertentu yang bisa mempunyai tanah dengan Hak Milik

(3) Orang asing yang sesudah berlakunya Undang-Undang ini memperoleh hak milik karena pewarian tanpa wasiat atau percampuran harta karena perkawinan, demikian pula warga negara Indonesia yang mempunyai hak milik dan setelah berlakunya Undang-Undang ini kehilangan kewarga-negaraannya wajib melepaskan hak itu di dalam jangka waktu satu tahun sejak diperolehnya hak tersebut atau hilangnya kewarga-negaraan itu. Jika sesudah jangka waktu tersebut lampau hak milik itu tidak dilepaskan, maka hak 
tersebut hapus karena hukum dan tanahnya jatuh pada Negara, dengan ketentuan bahwa hak-hak pihak lain yang membebaninya tetap berlangsung.

(4) warga negara Indonesia yang disampingnya memiliki kewarganegaraan asing berlaku ketentuan ayat (3)

Pasal ini memuat 4 (empat) ayat dimana ayat pertama mengatur tentang subjek Hak Milik dalam arti orang (natuural person) yang berkewarganegaraan Indonesia, ayat kedua mengatur tentang subjek Hak Milik dalam arti badan hukum (rechts persoon), ayat ketiga memuat 3(tiga) materi pengaturan yakni perolehan tanah Hak Milik karena percampuran harta dari perkawinan, perolehan tanah Hak Milik oleh WNA karena pewarisan tanpa wasiat, serta status kepemilikan tanah Hak Milik bagi orang yang kehilangan kewarganegaraannya dan ayat (4) mengatur tentang larangan kepemilikan tanah oleh orang yang disamping berkewarganegaraan Indonesia (WNI) yang memiliki status kewarganegaraan lain. Ketentuan pada ayat (1) dan ayat (2) sudah sangat jelas dan tegas sehingga tidak perlu dikritisi atau diperdebatkan. Ayat (3) memuat aturan bahwa negara memberikan pembatasan pada subjek hak untuk mengalihkan hak atas tanahnya karena perolehan tanah tersebut terjadi pada lembaga yang dibolehkan secara hukum (perkawinan campuran dan pewarisan tanpa wasiat) namun subjek/salah satu subjek haknya terhalang karena staus kewarganegaraannya atau karena subjek hak telah memiliki tanah HM dan kemudian kehilangan kewarganegaraannya. Adapun pembatasan negara dimaksud adalah pemberian jangka waktu untuk satu tahun untuk mengalihkan hak atas tanahnya berikut sanksinya. Apabila syarat tersebut tidak terpenuhi, maka tanah jatuh kepada negara. Argumentasinya, sistem kewarganegaraan tunggal dalam UU No. 62 tahun 1958 dan azas nasionalitas pada UUPA menjadi dasar pembatasan kepemilikan tanah karena peristiwa/perbuatan/keadaan hukum tertentu.

Terhadap pasal 21 ayat (3) ini diajukan Uji Konstitusional oleh Ike Farida bersamaan dengan pengujian Pasal 29 ayat (1) Undang-undang Nomor 1 Tahun 1974 tentang Perkawinan.Pasal 21 ayat (3) UUPA dan Pasal 29 ayat (1) UU Perkawinan dinilai bertentangan dengan Undang-Undang Dasar 1945. Alasannya, secara hukum perkawinan campuran dipebolehkan dan untuk menjamin kepastian kedudukan 
harta kekayaan masing-masing pihak selama masa perkawinan, diperkenankan untuk membuat perjanjian kawin dengan ketentuan harus dibuat sebelum atau pasa saat perkawinan berlangsung. Batasan waktu pembuatan perjanjian tersebut dianggap merugikan WNI yang menikah dengan WNA karena menghalangi WNI dalam mengakses Hak Milik atau HGB. Disamping itu, berdasarkan Pasal 35 ayat (1) UU Perkawinan, sejak pernikahan semua harta yang diperoleh semasa perkawinan demi hukum menjadi harta bersama apabila tidak didahului/disertai dengan perjanjian kawin. Atas pertimbangan ini, Ike Farida mengadu secara konstitusional kepada Mahkamah Konstitusi dengan mengetengahkan kasus yang sama yang dialami oleh beberapa orang yang melaksanakan perkawinan campuran diantaranya : Merry Anna Nun (WNI menikah dengan WNA Amerika Serikat ditolak pengajuan kredit KPR dengan alasan tidak adanya perjanjian kawin), Windi Nur Afifah (WNI menikah dengan WNA Belanda pengajuan kasus balik nama atas pembelian tanah HGB ditolak dengan alasan suaminya WNA), Muntini Cooper (WNI menikah dengan WNA Australia perohonan pengajuan kredit KPR ditolak karena tidak ada perjanjian kawin), Farida Indriani (WNI menikah dengan WNA Bangladesh, pengajuan fasilitas kredit KPR HGB ditolak dengan alasan tidak ada perjanjian kawin).

Pengajuan uji konstitusional tersebut dikabulkan sebagian sebagaimana tertuang dalam putusan Mahkamah Konstitusi Nomor : 69/PUUXIII/2015 yang isi pokok putuannya adalah bahwa perjanjian kawin tentang kedudukan harta masing-masing pihak(suami dan istri) yang diperoleh selama masa perkawinan boleh dibuat selama masa perkawinan, jadi tidak dibatasi pada sebelum atau pada saat perkawinan. Dalam kasu ini, Mahkamah Konstitusi tidak mengabulkan permohonan Ike Farida terkait Pasal 21 ayat (3) UUPA karena pasal ini sudah selaras dengan konstitusi.

Paper ini juga mempersoalkan ayat (4) dan mendapat perhatian lebih dibandingkan ayat sebelumnya karena menurut pendapat penulis, ayat tersebut memuat norma yang bersifat kontradiktif. Pertentangan tersebut terlihat dari materi pengaturan norma dimana di satu sisi secara tegas melarang pemilikan sementara di sisi lain mengikuti konsekuensi toleransi waktu 1 (satu) tahun untuk mengalihkan haknya berikut sanksinya sebagaimana ketentuan ayat (3). 
Integrasi ketentuan UUPA dan UU No. 62 Tahun 1958 dan pembatasan pada Pasal 21 ayat (3) UUPA tersebut menjadi logis sehingga mudah diterima secara nalar, namun tidak demikian pada ayat (4). Prinsip kewarganegaraan tunggal sebagaimana tertuan dalam peratuan perundang-undangan tentang kewarganegaraan di Indonesia sebenarnya hanya berlaku di dalam teritori Republik Indonesia. Apabila seseorang mendapatkan kewarganegaraan dari negara lain sehingga berstatus dwikewarganegaraan, maka keadaan tersebut membawa dampak pada pembatasan-pembatasan tertentu, termasuk dalam konteks makalah ini berupa pembatasan akses kepemilikan tanah dengan status Hak Milik. Pada prinsipnya, larangan status kewarganegaraan ganda yang dimiliki seseorang menurut penulis tidak selaras dengan perkembangan masyarakat yang saat ini tidak mungkin lepas dari pergaulan global. Dalam hal demikian, saya sependapat dengan Mahfud MD sebagaimana opini di Kompas (Mahfud, $2016: 7)$.

Prinsip kehidupan bernegara yang penting adalah bahwa ketika negara telah terbentuk, termasuk Indonesia sebagian kebebasan warga negara diserahkan kepada negara melalui mekanisme pembentukan hukum.
Kontekstualisasi dengan kasus ini secara yuridis adalah hukum yang terkait subjek Hak Milik atas tanah sinkronisasinya dengan status kewarganegaraan subjek haknya, sehingga meskipun setiap orang berhak atas properti yang dihasilkan dari jerih payahnya sendiri, kepemilikan tersebut dibatasi oleh ketentuan negara tentang ketentuan status kewarganegaraan.

\section{Simpulan}

1. Nilai-nilai dibalik norma penggolongan penduduk/pembedaan ras yang dibuat oleh pemerintah kolonial berjiwa feodalisme dan individualisme yang sangat merendahkan golongan pribumi/bumiputera karena mereka menganggap bahwa hukum tertulis tinggi kedudukannya daripada hukum tidak tertulis.

2. Merujuk pada pendapat beberapa ahli hukum tentang pengertian Politik Hukum, maka kedudukan Pasal II Aturan Peralihan hakikatnya merupakan ruang bagi politik hukum yang memberikan pijakan bagi pemerintah untuk melakukan pemilihan hukum-hukum apa yang akan diberlakukan.

3. Ketentuan subyek Hak Milik atas tanah dalam Pasal 21 ayat (1), ayat (2), ayat (3), telah sinkron dengan 
politik hukum tentang kewarganegaraan, namun demikian ayat (4) memuat norma kontradiktif sehingga kurang selaras dengan politik hukum tersebut.

\section{Daftar Pustaka}

\section{Buku}

Busroh, Abu Daud, 1990, Ilmu Negara, Jakarta : Bumi Aksara.

Departemen Pendidikan Nasional, 2014, Kamus Besar Bahasa Indonesia, Jakarta : Gramedia Pustaka Utama.

Hartono, C.F.G. Sunaryati, 1991, Politik Hukum Menuju Satu Sistem Hukum Nasional, Bandung : Alumni.

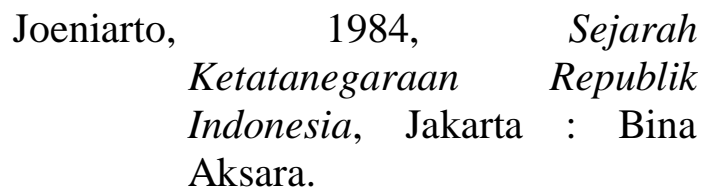

Kranenburg dan Sabaroedin, 1983, Ilmu Negara Umum, Jakarta: Pradnya Paramita.

Kusumaatmadja, Mochtar, 2006, Konsep-konsep Hukum dalam Pembangunan, Cetakan kedua, Bandung : Alumni.

Lev, Daniel S., 1990, Hukum dan Politik di Indonesia (Kesinambungan dan Perubahan), Jakarta : LP3ES.
Lukito, Ratno, 2013, Tradisi Hukum Indonesia, Cianjur : IMR Press.

MD, Moh. Mahfud 2014, Politik Hukum di Indonesia , Jakarta : Rajawali Press.

Rahardjo, Satjipto 2006, Ilmu Hukum, Bandung : Alumni.

Subekti, 2001, Pokok-Pokok Hukum Perdata, Jakarta : Intermasa.

Soedarto, 1986, Hukum dan Hukum Pidana, Bandung : Alumni.

Sutami, Siti, 2007, Pengantar Tata Hukum Indonesia, Bandung : Refika Aditama.

Wahjono, Padmo, 1986, Indonesia Negara Berdasarkan atas Hukum, Jakarta : Ghalia Indonesia.

Makalah

Nusantara, Abdul Hakim Garuda, 1985 , "Politik Hukum Nasional", makalah disampaikan pada Karya Latihan Bantuan Hukum (Kalabahu), diselenggarakan Yayasan LBH Indonesia dan LBH Surabaya.

\section{Surat Kabar}

Moh. Mahfud MD, "Pengaturan Dwikewarganegaraan, Kompas, tanggal 07 September 2016.

\section{Peraturan Perundang - Undangan}

Undang-Undang Nomor 1 Tahun 1974 tentang Perkawinan.

Undang-Undang Nomor 5 Tahun 1960 tentang Ketentuan Dasar Pokok-Pokok Agraria. 
Undang-Undang Nomor 12 Tahun 2006 tentang Kewarganegaraan.

\section{Putusan Pengadilan}

Putusan Mahkamah Konstitusi Nomor : 69/PUU-XIII/2015 tentang
Perjanjian Kawin Kaitannya Kepemilikan Tanah Hak Milik dan Tanah Hak Guna Bangunan dalam Perkawinan Campuran 